\title{
Magdalena Pastuchowa, Ukryte dziedzictwo. Ślady dawnej leksyki w słownictwie wspótczesnej polszczyzny, Wydawnictwo Uniwersytetu Śląskiego, Katowice 2008, ss. 170
}

Książka Magdaleny Pastuchowej sytuuje się w obszarze jej badań nad „leksykalnymi śladami” staropolszczyzny we współczesnym języku polskim. Autorkę interesuje to, „w jaki sposób historia pozostaje obecna w dzisiejszym słownictwie, jak można szukać śladów dawnej leksyki we współczesnym zasobie leksykalnym" (s. 9). Próbuje zatem zrekonstruować sposoby istnienia leksykalnej tradycji językowej w polszczyźnie. Przyjmuje stanowisko badawcze, o którego motywacji pisze następująco: „Taka postawa, w myśl której zakłada się badanie historii w celu zrozumienia współczesności, nieobca jest także pracom historycznym czy filozoficznym. Barbara Skarga w swojej książce pod znamiennym tytułem Ślad i obecność pisze: «Ślad odsyła do przeszłości, do tego, co było, ale już nie jest, przynajmniej tu i teraz. To znak fenomenu z przeszłości, czegoś, co się wydarzyło, minęło, pozostawiło jednak swoją pieczęć mniej lub bardziej wyraźna, taka właśnie jak skorupy wykopywane przez archeologa, służące za dowód istnienia tej lub innej kultury. [...] Gdyby przeszłość nie pozostawiała po sobie śladów, byłaby dla nas całkowicie niedostępna»" (s. 8).

O przedmiocie swojej pracy autorka pisze: „Przedmiotem mojej rozprawy uczyniłam tę część zasobu leksykalnego współczesnej polszczyzny, która w jakiś sposób, najczęściej mało wyrazisty, przechowuje dawne słownictwo polskie. Stąd nadrzędny tytuł: Ukryte dziedzictwo. [W przypisie autorka wyjaśnia, że interesują ją jednostki leksykalne, „w których obserwować można jedynie «pogłos» przeszłości", a nie takie, które zostały bez zmiany odziedziczone z prasłowiańszczyzny - B.W.]. Przedstawiona rozprawa jest studium słowotwórczo-porównawczym i to określenie precyzuje, jakiego poziomu języka dotyczą rozważania, a jednocześnie stanowi deklarację postawy badaw- 
czej. Przyjmuję bowiem, że nie ma wyraźnej granicy między słowotwórstwem i leksyką, a ściślej mówiąc, między słownictwem motywowanym i niemotywowanym, gdyż struktura słowotwórcza nie jest wartością stałą danego leksemu" (s. 8-9).

W związku z tym przekonaniem autorki pozostaje przyjęta przez nią metodologia, w której procedury badawcze słowotwórstwa współistnieją z koncepcjami leksykologicznymi. W odniesieniu do teoretyczno-metodologicznych paradygmatów językoznawstwa M. Pastuchowa stoi na gruncie strukturalizmu, traktuje go jednak ,instrumentalnie”: „metodologia strukturalna jest dla mnie środkiem, celem natomiast - obserwacja języka jako narzędzia komunikacji. Postawa taka okazuje się szczególnie potrzebna w pracach, których zadaniem jest pokazywanie obszarów granicznych, odnoszących się do więcej niż jednego poziomu języka" (s. 11). Wypada się z autorką zgodzić i stwierdzić, że zastosowana metodologia jest uzasadniona i adekwatna z jednej strony do zgromadzonego materiału językowego, a z drugiej - do założonych celów pracy.

O wartości rozprawy Magdaleny Pastuchowej stanowią - moim zdaniem przede wszystkim następujące aspekty i elementy:

1. Bogactwo materiału językowego. Składa się nań zbiór „około 1500 współczesnych leksemów i połączeń wyrazowych, które w jakiś sposób odnoszą się do dawnego, niezachowanego zasobu leksykalnego polszczyzny" (s. 163). (Autorka zdecydowała się gruntownie opracować tę materiałową podstawę rozprawy i opublikować w formie osobnego leksykonu, co należy uznać za ze wszech miar trafną decyzję. Ma rację, gdy pisze: „Mam nadzieję, ze przygotowana publikacja będzie nie tyko uzupełnieniem niniejszej monografii, ale także inspiracją do dalszych prac nad leksykologia historyczną", s. 164). W rozprawie autorka zaprezentowała analizę i interpretację 220 spośród nich, ale wnioski oparte są na analizie całości materiału. Pochodzi on ze źródeł leksykograficznych: Stownika staropolskiego, Stownika polszczyzny XVI wieku i słownika Lindego w zakresie słowników historycznych (sondażowo autorka wyzyskała też Stownik wileński i Stownik warszawski), Uniwersalnego słownika języka polskiego pod redakcją Stanisława Dubisza w zakresie współczesnej polszczyzny; autorka korzystała też ze słowników etymologicznych.

2. Imponujące zaplecze erudycyjne rozprawy. Spis literatury przedmiotu (s. 155-162) obejmuje 160 pozycji (w językach: polskim, angielskim, niemieckim, włoskim, rosyjskim, ukraińskim, czeskim i słowackim), z czego znacznie więcej niż połowa (100 pozycji) to książki, nierzadko bardzo obszerne (a trzeba pamiętać, że temat rozprawy bynajmniej nie należy do obszaru zagadnień intensywnie eksploatowanych w językoznawstwie polonistycznym). Warto przy tym podkreślić, że nie chodzi tu bynajmniej o erudycyjny popis: znajomość rozległej literatury przedmiotu, także spoza obszaru językoznawstwa (filozo- 
fia, historia, kulturoznawstwo, metodologia nauki itp.) ma charakter „sfunkcjonalizowany", jej wyniki, umiejętnie wyzyskane przez autorkę, są obecne i widoczne w tekście jej pracy, która dzięki temu zyskuje na głębi i gruntowności.

3. Gruntowność, wielostronność i wnikliwość analizy i interpretacji. W szczególności należy tu podkreślić dociekliwość autorki w tropieniu śladów przeszłości we współczesnej polszczyźnie, jej pomysłowe i sugestywne interpretacje, które są chyba w równym stopniu wynikiem z jednej strony talentu, intuicji i wrażliwości semantycznej, a z drugiej - doświadczenia badawczego w tym zakresie i gruntownej znajomości średniowiecznego piśmiennictwa polskiego oraz literatury naukowej na jego temat.

4. Liczne, ważne i interesujące uwagi i refleksje teoretyczno-metodologiczne w takich kwestiach, jak relacje między synchronią a diachronią, pojęcia leksykalizacji (tu szczególnie ważne i płodne naukowo szerokie rozumienie leksykalizacji i wynikająca z niego nowa definicja wyrazu, który uległ leksykalizacji: „Przyjmuję [...], że wyraz zleksykalizowany to taki, który ma znaczenie odmienne - wzbogacone lub ograniczone - w stosunku do tego, jakie wynika z jego budowy słowotwórczej, widocznej lub zatartej", s. 87), gramatykalizacji i leksykalnej zmiany semantycznej, kompetencji i świadomości językowej itd.

5. Aksjologiczne implikacje tez autorki (podkreślającej społeczne znaczenie poczucia wspólnoty językowej i rolę w tym względzie identyfikacyjnej funkcji języka).

6. Bardzo interesujące i ważne wyniki naukowe (jako skutek wszystkich wyliczonych walorów). Niepodobna tu wymienić wszystkich, zwłaszcza licznych szczegółowych. Ograniczę się do przykładowego wskazania kilku spośród (moim zdaniem) najciekawszych i najważniejszych:

a) skonstruowanie instrumentarium badawczego, które pozwala:

„-- wskazać w zasobie słownikowym dzisiejszej polszczyzny te jednostki, w których «ślady przeszłości» są «zakamuflowane», dane nie wprost,

- opisać mechanizmy, które umożliwiają lub ułatwiają odnalezienie we współczesnym słownictwie dziś nieobecnych jednostek leksykalnych, których istnienie potwierdzają leksykony dawnej polszczyzny,

- zinterpretować przyczyny, które powoduja, iż osłabia się lub zrywa związek konstrukcji słowotwórczych z leksemami motywującymi” (s. 150);

b) przekonujące wykazanie, że leksykalizacja obejmuje o wiele większy, niż się powszechnie sądzi, odsetek jednostek genetycznie niepierwotnych;

c) wykazanie, że „o stabilności polskiego słownictwa stanowią przede wszystkim leksemy pojemne znaczeniowo (polisemiczne)" (s. 151).

d) przekonujące dowiedzenie ważnej tezy, że „wyrazy zleksykalizowane mają większą «szansę na przetrwanie», gdyż ich znaczenie nie jest sztywno 
związane z budową morfemową; konsekwencją tego jest osłabienie roli znaczenia strukturalnego w interpretacji konstrukcji słowotwórczych, gdyż konieczna okazuje się znajomość znaczenia leksykalnego" (s. 151).

W świetle swojej rozprawy Magdalena Pastuchowa prezentuje się jako badaczka uzdolniona, pracowita, samodzielna i doświadczona. Jej warsztat naukowy odznacza się dwiema szczególnie cennymi i pożądanymi cechami. Są to:

1. Solidne podstawy materiałowe formułowanych tez i wniosków;

2. Postawa badawcza cechująca się sumiennością i skrupulatnością na każdym etapie postępowania badawczego, umiejętnością łączenia gruntownej, wielostronnej i szczegółowej analizy z dobrze uzasadnioną, podbudowaną obfitym materiałem syntezą, a także chwalebną ostrożnością w wyciaganiu wniosków i formułowaniu tez.

Dzięki takiemu warsztatowi badawczemu Magdalena Pastuchowa osiagnęła wiele ważnych i wartościowych wyników naukowych (kilka z nich wskazałem), które weszły do trwałego dorobku językoznawstwa polskiego. Poczesne miejsce wśród nich zajmują te $\mathrm{z}$ recenzowanej książki. 